\title{
Comparison of traditional field retting and Phlebia radiata Cel 26 retting of hemp fibres for fibre-reinforced composites
}

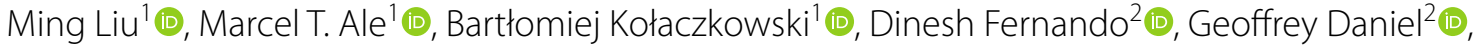 \\ Anne S. Meyer ${ }^{1}\left(\mathbb{B}\right.$ and Anders Thygesen ${ }^{1 *}(\mathbb{C}$
}

\begin{abstract}
Classical field retting and controlled fungal retting of hemp using Phlebia radiata Cel 26 (a mutant with low cellulose degrading ability) were compared with pure pectinase treatment with regard to mechanical properties of the produced fibre/epoxy composites. For field retting a classification of the microbial evolution (by gene sequencing) and enzyme profiles were conducted. By phylogenetic frequency mapping, different types of fungi, many belonging to the Ascomycota phylum were found on the fibres during the first 2 weeks of field retting, and thereafter, different types of bacteria, notably Proteobacteria, also proliferated on the field retted fibres. Extracts from field retted fibres exhibited high glucanase activities, while extracts from P. radiata Cel 26 retted fibres showed high polygalacturonase and laccase activities. As a result, fungal retting gave a significantly higher glucan content in the fibres than field retting (77 vs. 67\%) and caused a higher removal of pectin as indicated by lower galacturonan content of fibres (1.6\%) after fibres were retted for 20 days with P. radiata Cel 26 compared to a galacturonan content of $3.6 \%$ for field retted fibres. Effective fibre stiffness increased slightly after retting with P. radiata Cel 26 from 65 to $67 \mathrm{GPa}$, while it decreased after field retting to $52 \mathrm{GPa}$. Effective fibre strength could not be determined similarly due to variations in fibre fracture strain and fibre-matrix adhesion. A maximum composite strength with 50 vol\% fibres of $307 \mathrm{MPa}$ was obtained using $P$. radiata Cel 26 compared to $248 \mathrm{MPa}$ with field retting.
\end{abstract}

Keywords: Hemp fibre, Field retting, Phlebia radiata Cel 26, Microbial community, Enzyme profiling, Composite strength

\section{Introduction}

The use of cellulosic fibres in high grade composites has gained increased interest over the last decade (Faruk et al. 2012; Liu et al. 2016b). Plant fibres originating from hemp (Cannabis sativa L.) are considered a particularly promising renewable raw material for production of high quality reinforcement of composite materials due to their high stiffness and strength to weight ratio (Faruk et al. 2012).

The cellulose-rich hemp fibres are present in the outermost bast layer of the hemp stem consisting of (a)

\footnotetext{
*Correspondence: athy@kt.dtu.dk

${ }^{1}$ Center for Bioprocess Engineering, Department of Chemical and Biochemical Engineering, Technical University of Denmark, Søltofts Plads 229, 2800 Kongens Lyngby, Denmark

Full list of author information is available at the end of the article
}

epidermis, (b) several layers of primary fiber cells (cortex layer with large cells each containing a good-sized secondary wall), (c) layers of secondary cells that are smaller with a thinner secondary wall and (d) parenchyma cells. In the bast layer the primary and secondary fiber cells are bonded together by a pectinaceous matrix, the middlelamella. The retting process is used to separate these cellulosic fibres by degrading the parenchyma cells, as well as in the middle lamella between fibres (Liu et al. 2015a, b). The removal of non-cellulosic components and separation of the cellulose fibers can also improve interface bonding between fibers and composite matrix polymers and thus increase the mechanical properties of the fiber reinforced composites (Li et al. 2009; Liu et al. 2016a, b). 
During classic field retting in many European countries, hemp plants are cut and seeds collected with a specialized harvesting machine. Thereafter the plant stems are left on the field for a long period (20-70 days), processed into bales and finally separated into fibres and shives. The retting process is uncontrolled microbial wise, which can result in loss of fibre strength due to cellulase activity secreted by proliferation of native microorganisms on the hemp stems (Liu et al. 2015a). This process has been studied and involves fungi such as Cladosporium sp. and Cryptococcus sp. as well as bacteria including Escherichia coli (Brown and Sharma 1984; Ribeiro et al. 2015). The characteristics of the microorganisms involved in field retting, and their expressed enzymes should be studied to acquire a better understanding of the influence of field retting on chemical composition and mechanical properties of the fibres.

In order to avoid degradation of cellulose and reduction of fibre mechanical properties microbiologically controlled retting using selected fungi to degrade noncellulosic components in the fibres has been investigated (Thygesen et al. 2007; Liu et al. 2015b). Phlebia radiata Cel 26 and Ceriporiopsis subvermispora, belonging to the Basidiomycota phylum, produce less cellulase enzymes compared to their wild types (Nyhlen and Nilsson 1987). P. radiata Cel 26 has been found most selective in pectin degradation resulting in higher fibre strength (Liu et al. 2015a). Nevertheless, the determination of enzyme activity in the extracts of $P$. radiata Cel 26 retted hemp fibres can provide knowledge on how the retting process can be optimized to produce high quality fibres.

It can thereby be hypothesized that higher cellulase activities would be detected in enzyme extracts from field retted hemp fibres compared to $P$. radiata Cel 26 retted fibres and that any higher cellulase activity in field retted samples would correlate to decreased mechanical properties. As a result, it can be expected that fibres with low mechanical properties should be obtained after field retting.

The objective of this study was to compare classical field retting with a pure microbial retting approach $(P$. radiata Cel 26) and a pure enzymatic retting approach (pectinase enzymes) based on mechanical properties of the obtained hemp fibre reinforced composites. Genetic identification and environmental scanning electron microscopy (ESEM) observation of bacteria and fungi was carried out to identify their abundance on hemp fibre surfaces. Enzymatic and microbial characteristics were linked to changes in chemical composition of fibres and mechanical properties of the fibres and fibre/epoxy composites. Finally the changes in microbial community, fibre composition and fibre mechanical properties were followed versus the retting duration. The correlation between microbial retting duration, chemical composition of fibres, and mechanical properties of produced composites was thereby established.

\section{Materials and methods \\ Raw materials and fibre treatments}

Hemp (Cannabis sativa L.), variety USO-31, was sown on May 5th 2013 [N 48.8526 ${ }^{\circ}$ E 3.0190 (WGS84)] by Bafa Neu GmbH and harvested on Sep 6th 2013 (Liu et al. 2015a). Whole hemp plants were cut $5 \mathrm{~cm}$ above ground to obtain untreated bast fibres. Fibres representing the whole stems were applied in the study.

\section{Field retting}

The hemp was harvested with a Deutz-Fahr 6090 HTS leaving the chopped plant stems on the field. Field retting was conducted for 7, 14 and 20 days after harvest as previously reported (Liu et al. 2015a). After field retting, hemp stem samples for microbial evolution study and enzyme activity measurements were stored frozen until analysis, while for tensile test, chemical composition analysis and composite manufacturing, the samples were dried at $40^{\circ} \mathrm{C}$ directly after treatment.

\section{Washing and autoclaving followed by fungal retting and pectinase treatment}

Whole hemp stems were cut into $15 \mathrm{~cm}$ long pieces and washed three times at $40^{\circ} \mathrm{C}$ for $5 \mathrm{~min}$ each using $500 \mathrm{~mL}$ water per $15 \mathrm{~g}$ stems. Fungal retting with $P$. radiata $\mathrm{Cel}$ 26 was carried out on hemp stem pieces after autoclaving the washed stem pieces at $121{ }^{\circ} \mathrm{C}$ for $60 \mathrm{~min}$ (HTT) to avoid contamination with wild fungi. The fungal retting was conducted for 7, 14 and 20 days in $1 \mathrm{~L}$ Erlenmeyer flasks ( $15 \mathrm{~g}$ hemp stems of $15 \mathrm{~cm}$ in length per flask) at $28{ }^{\circ} \mathrm{C}$. P. radiata Cel 26 was obtained from the Swedish Agricultural University, Uppsala, Sweden (Nyhlen and Nilsson 1987; Liu et al. 2015b). After fungal retting, hemp stem samples for microbial evolution study and enzyme activity measurements were stored frozen, while for tensile test, chemical composition analysis and composite manufacturing, the samples were dried at $40^{\circ} \mathrm{C}$ directly after treatment.

Autoclave pretreatment of the washed hemp stems was both tested at $121{ }^{\circ} \mathrm{C}$ for 30 and $60 \mathrm{~min}$. The following pectinase treatment was performed for $90 \mathrm{~min}$ on hand peeled hemp bast. This pectinase treatment was both tested with and without $30 \mathrm{~min}$ autoclave pretreatment (Liu et al. 2016b).

\section{Fungal and bacterial classification by gene sequencing}

Hemp fibres were isolated manually from stems by removing xylem using a scalpel. Approximately $50 \mathrm{mg}$ of sample $\left(2 \mathrm{~mm}^{2}\right)$ placed into $2 \mathrm{~mL}$ Eppendorf tubes was 
extracted directly for obtaining genomic DNA using PowerBiofilm $^{\mathrm{TM}}$ DNA Isolation Kit (MO-BIO, Carlsbad, USA) according to the manufacturer's instructions. Polymerase chain reaction (PCR) amplification for both bacterial and fungal DNA was carried out using a $\mathrm{C}_{1000}{ }^{\mathrm{TM}}$ thermo-cycler (BIO-RAD, Hercules, USA). Each DNA sample $(1 \mu \mathrm{L})$ was used as template in the PCR reactions (Sun et al. 2015). The universal bacterial $16 \mathrm{~S}$ ribosomal ribonucleic acid (16S rRNA) primers used were 27F (5'-AGAGTTTGATCATGGCTCA-3') and 1492R (5'-CGGTTACCT TGTTACGACTT-3'). The fungal primer set was ITS5 (5'-GGAAGTAAAAGTCGTAACAAGG-3') and ITS4 (5'-TCCTCCGCTTATTGATATGC-3') (Eurofins Genomics, Ebersberg, Germany) (White et al. 1990; Gardes et al. 1991). The internally transcribed spacer (ITS) is the DNA situated between the small-subunit rRNA and the large-subunit rRNA genes in the chromosome or the correspondingly transcribed region in the polycistronic rRNA precursor transcript. Extracted DNA $(1 \mu \mathrm{L})$ was added to a PCR master mix $(49 \mu \mathrm{L})$ containing $0.5 \mu \mathrm{M}$ of primers, Phusion HF buffer (F-518), $200 \mu \mathrm{M}$ dNTPs and $0.5 \mathrm{U}$ Phusion Hot Start II DNA polymerase (\#F-549L; Thermo Fisher Scientific, Waltham, USA) (Ale et al. 2016).

PCR products were purified using GFX PCR DNA and Gel Band Purification Kit (GE28-9034-70 SigmaAldrich, Gillingham, UK). Cloning was performed using the pJet1.2/Blunt cloning vector $(50 \mathrm{ng} / \mu \mathrm{L})$ and $\mathrm{T} 4 \mathrm{DNA}$ ligase $(5 \mathrm{U} / \mu \mathrm{L})$. Ligation was carried out according to the manufacturer's instructions (CloneJET PCR Cloning Kit \#K1231, Thermo Scientific, USA) and the ligated product was used for transformation of electro-competent $E$. coli DH5 $\alpha$ using BioRad Micropulser (BioRad, Hercules, USA). Purified plasmids were sequenced using the $27 \mathrm{~F}$ primer for bacteria and the ITS4 primer for fungi synthesized by the company Macrogen Europe (Amsterdam, The Netherlands). The identified sequences are published in the EMBL Nucleotide Sequence Database with the accession numbers LT622055-LT622085 outlined in Tables 2 and 3 for bacteria and fungi, respectively.

A GenBank nucleotide database search was conducted using the BLAST algorithm (Basic Local Alignment Search Tool) to determine the closest relative of partial $16 \mathrm{~S}$ gene sequences (Maidak et al. 1999). For each DNA sequence, a multiple alignment was created by Clustal W (Thompson et al. 1994). Evolutionary analysis and a phylogenic tree were constructed in Mega 6.0 with the Kimura two-parameter model (Kimura 1980). The reliability of the branches was evaluated with non-parametric bootstrapping (100 replicates). All positions with less than $95 \%$ site coverage were eliminated (complete deletion option). That means that fewer than $5 \%$ alignment gaps, missing data and ambiguous bases were allowed at any position.

\section{Protein extraction and enzyme activity assay}

Hemp bast fibres were gently peeled from field retted and $P$. radiata Cel 26 retted hemp stems. For enzyme extraction, $4 \mathrm{~g}$ of bast fibres were submersed in $40 \mathrm{~mL}$ of $20 \mathrm{mM}$ citrate buffer ( $\mathrm{pH}$ 6.0) supplemented with $0.1 \%$ $(\mathrm{v} / \mathrm{v})$ Tween 20 and $0.25 \mathrm{mM}$ dithiothreitol in a glass tube at $0{ }^{\circ} \mathrm{C}$ and shaken at $120 \mathrm{rpm}$ for $1 \mathrm{~h}$. For each sample, the crude enzyme extracts were concentrated until the volume was reduced to $3.0 \mathrm{~mL}$ (Suwannarangsee et al. 2014). After concentrating, the enzyme extracts were kept at $4{ }^{\circ} \mathrm{C}$ for activity assay. Protein content of enzyme extracts were determined using Bovine serum albumin as standard (Bradford 1976).

The pectinolytic, cellulolytic and hemicellulolytic enzyme activities were determined in crude enzyme extracts from the field retted and $P$. radiata Cel 26 retted samples at $40{ }^{\circ} \mathrm{C}$ in $20 \mathrm{mM}$ citrate buffer ( $\mathrm{pH} 6.0$ ). Glucanase, polygalacturonase, galactanase and xyloglucan (XG)-specific endoglucanase activities were determined by measuring formation of reducing ends. The substrates used were for glucanase $10 \mathrm{~g} / \mathrm{L}$ carboxymethyl cellulose (Suwannarangsee et al. 2014), for polygalacturonase $2 \mathrm{~g} / \mathrm{L}$ polygalacturonic acid (Thomassen et al. 2011), for galactanase $5 \mathrm{~g} / \mathrm{L}$ potato galactan (Michalak et al. 2012) and for xyloglucan $10 \mathrm{~g} / \mathrm{L}$ tamarind xyloglucan (Benko et al. 2008). Enzyme to substrate ratio of 5:1 (v/v) was used for all the enzyme activity assays. The amount of reducing sugars that were liberated was measured by using 4-hydroxybenzoic acid hydrazide as colorimetric agent (Lever 1973). One unit of enzyme activity was defined as the volume of crude enzyme extracts $(\mu \mathrm{L})$ required to liberate $1 \mu \mathrm{mol}$ reducing ends (glucose equivalents) per minute under the assay conditions.

Laccase activity was measured by monitoring the oxidation of Diammonium 2,2'-azino-bis(3-ethylbenzothiazoline-6-sulfonate) (ABTS) by the enzyme extracts at $420 \mathrm{~nm}$ (Li et al. 2008). ABTS has the CAS Number: 30931-67-0 and was bought at Sigma-Aldrich, Gillingham, UK (Product no. 10102946001). P. radiata Cel 26 produces low levels of $\mathrm{H}_{2} \mathrm{O}_{2}$ and other peroxidases, which show activity with ABTS in the presence of $\mathrm{H}_{2} \mathrm{O}_{2}$ (Srinivasan et al. 1995). Therefore, catalase (SigmaAldrich, Gillingham, UK) was added at $1000 \mathrm{U} /(\mathrm{mL}$ of enzyme extracts) into crude enzyme extracts and incubated for $1 \mathrm{~h}$ at $37{ }^{\circ} \mathrm{C}$ to remove $\mathrm{H}_{2} \mathrm{O}_{2}$. One unit of laccase activity was defined as the volume of crude enzyme extract $(\mu \mathrm{L})$ required to oxidize $1 \mu \mathrm{mol}$ ABTS per minute under the assay conditions. 


\section{Characterization of fibres \\ Chemical composition analysis}

Dried bast fibres were ground with a microfine grinder (IKA, MF 10.1; IKA ${ }^{\circledR}$-Werke GmbH, Staufen, Germany) through a 1-mm screen. Ground samples were extracted in a Soxhlet apparatus (Liu et al. 2015a) and the extractive-free fibres hydrolysed using a two-step sulfuric acid process (Sluiter et al. 2011). After acid hydrolysis, the hydrolysate was collected for monosaccharide analysis, and Klason lignin (i.e. residue of the hydrolysis) content was gravimetrically determined. The chemical composition of the hydrolysate was analysed by high-performance anion-exchange chromatography with pulsed amperometric detection (HPAECPAD) and with recovery values of the monosaccharides estimated from parallel runs (Arnous and Meyer 2008).

\section{Scanning electron microscopy of fibre surface}

Samples ( $5 \mathrm{~mm}$ long $\times 2 \mathrm{~mm}$ wide) were cut from bast fibre strips under a stereo microscope and fixed in $3 \% \mathrm{v} / \mathrm{v}$ glutaraldehyde, $+2 \%$ paraformaldehyde in $0.1 \mathrm{M} \mathrm{Na}$-cacodylate buffer ( $\mathrm{pH}$ 7.2). After fixation, the samples were dehydrated in aqueous ethanol using: 20, 40, 60, 80, 90 and $100 \%$ for $15 \mathrm{~min}$ in each solution. Subsequent dehydration was performed in 33, 66 and 100\% acetone in ethanol before samples were critical point dried using an Agar E3000 critical point dryer (Agar Scientific, Stansted, UK) with liquid $\mathrm{CO}_{2}$ as drying agent. Digital photos were taken using an XL 30 ESEM microscope (Philips, Eindhoven, Holland) operated at $10-15 \mathrm{kV}$ (Fernando and Daniel 2008).

\section{Tensile properties of fibres}

Bast fibre strips ( $60 \mathrm{~mm}$ long $\times 1 \mathrm{~mm}$ wide) of mass in the range of 5-20 mg were used for tensile testing (Liu et al. 2015a). Tensile testing was performed using an Instron Testing Machine 2710-203 equipped with a $1 \mathrm{kN}$ load cell (Instron ${ }^{\circledR}$, Buckinghamshire, United Kingdom). The gauge length was $10 \mathrm{~mm}$ and the displacement rate $0.5 \mathrm{~mm} / \mathrm{min}$ (corresponding to a strain rate of $5 \% \mathrm{~min}^{-1}$ ). Tensile testing was performed on 20 specimens for each treatment. The cross-sectional area $\left(\mathrm{A}_{\mathrm{f}}\right)$ was determined from measured fibre mass, length and density $\left[1.50 \mathrm{~kg} / \mathrm{dm}^{3}\right.$ (Cheung et al. 2009)]. Stiffness (linear regression in the strain interval 0.05$0.25 \%$ ), ultimate tensile strength (UTS), and failure strain were determined based on measured stress-strain curves.

\section{Composite manufacturing and mechanical properties Manufacturing of fibre/epoxy composites}

Composites were manufactured by manually aligning the treated hemp bast fibre strips resulting in unidirectional composites. Epoxy resin (Araldite ${ }^{\circledR}$ LY 1568) and its amine hardener (Aradur ${ }^{\circledR}$ 3489) both supplied by Huntsman Corporation, Houston, USA, were mixed at a 100/28 mass ratio and degassed in a vacuum oven. The setup for vacuum infusion and mould processing has been described (Liu et al. 2016b). After demoulding, composite samples with dimensions of $140 \mathrm{~mm} \times 10 \mathrm{~mm} \times 2 \mathrm{~mm}$ were obtained and then glass fibre/epoxy tabs with lengths of $50 \mathrm{~mm}$ were mounted on composite specimens using epoxy adhesive (DP 460; 3M, Minneapolis, USA).

The volumetric composition of the composites was varied by varying the fibre weight contents $\left(\mathrm{W}_{\mathrm{f}}\right)$ in the range $0-0.70 \mathrm{~g} / \mathrm{g}$ composite. When $\mathrm{W}_{\mathrm{f}}$ was below 0.30 , the composite specimens had irregular surfaces and their density $\left(\rho_{c}\right)$ was determined by the buoyancy method (Archimedes principle) using water as displacement medium. Otherwise the composite specimens had flat surfaces and $\rho_{\mathrm{c}}$ could be calculated based on their dimensions (i.e. length, width and thickness). The volumetric composition of composite samples was determined as previously described (Liu et al. $2016 b)$. In the composites, the porosity $\left(V_{p}\right)$ was assumed to increase linearly versus the fibre volume content $\left(\mathrm{V}_{\mathrm{f}}\right)$ based on a proportionality constant (porosity factor) $\alpha_{\mathrm{pf}}$ (Eq. 1). The porosity of hemp fibre reinforced composites can be separated into three main types: (a) fibre lumen; (b) voids among fibre bundles; and (c) voids at the interface between matrix polymer and fibre bundles (Liu et al. 2016a). The matrix correlated porosity factor $\left(\alpha_{\mathrm{pm}}\right)$ was assumed to be zero since no air bubbles were observed in the cured epoxy matrix by ESEM (Liu et al. 2016a).

$$
V_{p}=\alpha_{p f} \times V_{f}
$$

\section{Tensile properties of composites}

For tensile testing of the composite specimens, an Instron Testing Machine 5566 (Instron ${ }^{\circledR}$, Buckinghamshire, United Kingdom) with a load cell of $10 \mathrm{kN}$ was used. Strain measurements were conducted using two extensometers and the displacement rate was $1 \mathrm{~mm} / \mathrm{min}$ (corresponding to a strain rate of $2.5 \% \mathrm{~min}^{-1}$ ). Based on measured stress-strain curves, composite stiffness $\left(E_{c}\right)$ (linear regression in the strain interval $0.05-0.25 \%$ ) and $\mathrm{UTS}_{\mathrm{c}}$ were determined. For each treatment, at least ten specimens with varied fibre content were tested. The UTS and stiffness curves of the composites were compared by assessing the responses by linear regression comparison within the tested range of $\mathrm{V}_{\mathrm{f}}$. Effective fibre stiffness $\left(E_{f}\right)$ in the composites were thereby determined from Eq. 2 (Curtin 1993). The intercept was set equal to the measured matrix stiffness $\left(\mathrm{E}_{\mathrm{m}}\right)$.

$$
\begin{aligned}
E_{c} & =E_{m} V_{m}+E_{f} V_{f}=E_{m}\left(1-V_{f}-V_{p}\right)+E_{f} V_{f} \\
& \text { 年 } \\
E_{c} & =E_{m}\left(1-V_{f}-\alpha_{p f} V_{f}\right)+E_{f} V_{f} \\
& =E_{m}+V_{f}\left(E_{f}-E_{m}\left(1+\alpha_{p f}\right)\right)=E_{m}+k V_{f} \\
& \text { } \\
E_{f} & =k+E_{m}\left(1+\alpha_{p f}\right)
\end{aligned}
$$


where the subscripts $\mathrm{c}, \mathrm{f}$ and $\mathrm{m}$ indicate composite, fibres, and matrix, respectively and $k$ is the slope of the regression line, i.e. of $E_{c} v s$. $V_{f}$. The effective fibre strength cannot be calculated similarly due to effects of fibre-matrix adhesion and Weibull distribution of the fibre strength (Curtin 1993; Shah et al. 2016). It means that a part of the fibres are broken and not carrying load before the composite fails while some fibres still carry a reduced load due to their matrix adhesion. The composite strength was therefore calculated by linear regression for composites with 50 vol\% fibres based on interpolation.

\section{Results}

\section{Chemical composition of field retted and $P$. radiata Cel 26 retted fibres}

Table 1 shows the changes in chemical composition of the hemp fibres after autoclaving, field retting and $P$. radiata Cel 26 retting. Before the retting with $P$. radiata Cel 26 it was required to autoclave pretreat the hemp stems for $60 \mathrm{~min}$ to avoid fungal contamination. The HTT treatment reduced the galacturonan content from 8.3 to $4.5 \%$ while no significant effects happened to the cellulose, hemicellulose and lignin contents (Liu et al. 2016b) (Table 1). In addition, the effects of 30 and $60 \mathrm{~min}$ HTT time appeared to be similar. A reduction in galacturonan, arabinan, and xylan contents were noted with increasing retting time during both treatments (Table 1). During field retting, the galacturonan content gradually decreased from $8.3 \%$ for untreated fibres, to $5.4 \%$ after 7 days and to $3.1 \%$ after 14 and 20 days. In contrast, the galacturonan content decreased to a lower level of only $1.6 \%$ galacturonan during 20 days retting with $P$. radiata
Cel 26 partly due to the required HTT process. After 20 days arabinan and xylan contents decreased to 0.5 and $1 \%$, respectively, both by field retting and by retting with $P$. radiata Cel 26. In comparison to untreated fibres, no increase in glucan content was noted during field retting. In contrast, the relative glucan content in the hemp fibres increased after only 7 days of retting with $P$. radiata $\mathrm{Cel}$ 26 from 67 to $82 \%$ (Table 1). The retting with $P$. radiata Cel 26 also resulted in higher glucan content than the pectinase treatment (69-71\%) (Liu et al. 2016b).

Besides these changes, a slight increase in lignin content (i.e. lignin to carbohydrate ratio), particularly during field retting was noted presumably due to a lack of lignin degrading enzymes produced by the microbial retting flora. The increase can also be due to microbial biomass formation and that the degradation rate of lignin is much lower than that of other components i.e. pectin.

\section{Evolution of the microbial community during field retting}

The changes in chemical composition of fibres during field retting (Table 1) were accompanied by changes in the microbial community versus time. Figure 1 shows typical examples of the proliferation and pervasive action of fungi and bacteria on hemp fibre surfaces. In addition, gene sequencing provided identification and diversity of bacteria and fungi as shown in Tables 2 and 3, respectively. Phylogenetic trees of the bacterial and fungal community evolution during field retting are shown in Fig. 2a, b, respectively.

ESEM microscopy observation showed that neither bacteria nor fungal hyphae were present on the hemp fibre surface before field retting (Fig. 1a). After 7 days of

Table 1 Chemical composition of hemp fibres after different treatments

\begin{tabular}{|c|c|c|c|c|c|c|c|c|}
\hline \multirow[t]{2}{*}{ Treatment } & \multirow[t]{2}{*}{ Treatment period } & \multicolumn{7}{|l|}{ Amount (\%) } \\
\hline & & Glu & GalA & Gal & Ara & Xyl & Man & Lignin \\
\hline Untreated & 0 & $60.0(2.2)^{f}$ & $7.3(0.4)^{\mathrm{a}}$ & $2.1(0.2)$ & $1.3(0.3)$ & $1.2(0.1)$ & $3.0(0.3)$ & $4.4(0.3)^{d}$ \\
\hline Washed $40^{\circ} \mathrm{C}$ & $60 \min$ & $67.2(2.6)^{\text {de }}$ & $8.3(0.4)^{a}$ & $2.1(0.1)$ & $1.2(0.1)$ & $1.3(0.2)$ & $4.6(0.2)$ & $5.3(0.2)^{\mathrm{bcd}}$ \\
\hline HTT & $30 \mathrm{~min}$ & $67.0(1.3)^{\mathrm{de}}$ & $4.5(0.4)^{b}$ & $1.8(0.1)$ & $0.8(0.1)$ & $1.1(0.1)$ & $4.5(0.2)$ & $4.6(0.2)^{\mathrm{cd}}$ \\
\hline HTT & $60 \min$ & $67.9(2.8)^{\text {de }}$ & $5.5(0.8)^{\mathrm{cd}}$ & $2.1(0.3)$ & $1.1(0.3)$ & $1.4(0.2)$ & $3.5(0.4)$ & $5.0(0.3)^{\mathrm{cd}}$ \\
\hline \multirow[t]{3}{*}{ Field retting } & 7 days & $63.9(1.0)^{\mathrm{ef}}$ & $5.4(0.6)^{b c}$ & $2.0(0.2)$ & $0.7(0.2)$ & $1.1(0.2)$ & $4.0(0.4)$ & $5.3(0.9)^{\mathrm{bcd}}$ \\
\hline & 14 days & $70.2(0.5)^{\text {cde }}$ & $3.1(0.4)^{e f g}$ & $2.4(0.2)$ & $0.4(0.0)$ & $0.8(0.2)$ & $3.4(0.0)$ & $6.1(0.9)^{b c}$ \\
\hline & 20 days & $66.9(1.2)^{\text {de }}$ & $3.6(0.4)^{\text {def }}$ & $2.0(0.0)$ & $0.6(0.1)$ & $1.0(0.2)$ & $3.9(0.2)$ & $8.1(0.3)^{\mathrm{a}}$ \\
\hline \multirow[t]{3}{*}{ Fungal retting } & 7 days & $81.8(1.6)^{a b}$ & $4.2(0.2)^{\mathrm{de}}$ & $2.4(0.1)$ & $0.7(0.0)$ & $1.3(0.1)$ & $4.7(0.3)$ & $6.1(1.1)^{b c}$ \\
\hline & 14 days & $83.4(3.8)^{\mathrm{a}}$ & $2.0(0.2)^{g h}$ & $2.3(0.2)$ & $0.5(0.1)$ & $1.3(0.1)$ & $4.4(0.3)$ & $5.3(0.1)^{\mathrm{bcd}}$ \\
\hline & 20 days & $76.7(1.5)^{b c}$ & $1.6(0.0)^{\mathrm{h}}$ & $2.0(0.0)$ & $0.5(0.0)$ & $1.1(0.0)$ & $4.5(0.4)$ & $6.7(0.5)^{a b}$ \\
\hline Pectinase $^{A}$ & $90 \min$ & $71.8(0.8)^{\mathrm{cd}}$ & $4.3(0.2)^{\mathrm{cd}}$ & $1.7(0.0)$ & $0.7(0.0)$ & $0.9(0.0)$ & $5.6(0.1)$ & $4.8(0.6)^{c d}$ \\
\hline $\mathrm{HTT}+$ pectinase $^{\mathrm{A}}$ & $90 \mathrm{~min}$ & $69.5(3.9)^{\text {de }}$ & $2.9(0.3)^{f g}$ & $1.5(0.1)$ & $0.7(0.1)$ & $0.7(0.1)$ & $4.2(0.3)$ & $4.2(0.5)^{d}$ \\
\hline
\end{tabular}

Values are means (standard deviation) for three replicates. In each column, values that do not share a letter are significantly different at the $5 \%$ level

Glu glucan, GalA galacturonan, Gal galactan, Ara arabinan, Xyl xylan, Man mannan, Lignin Klason lignin

A With or without autoclave treatment (HTT) at 1 bar $\left(121^{\circ} \mathrm{C}\right)$ for $30 \mathrm{~min}$ before the pectinase treatment (Liu et al. 2016b) 

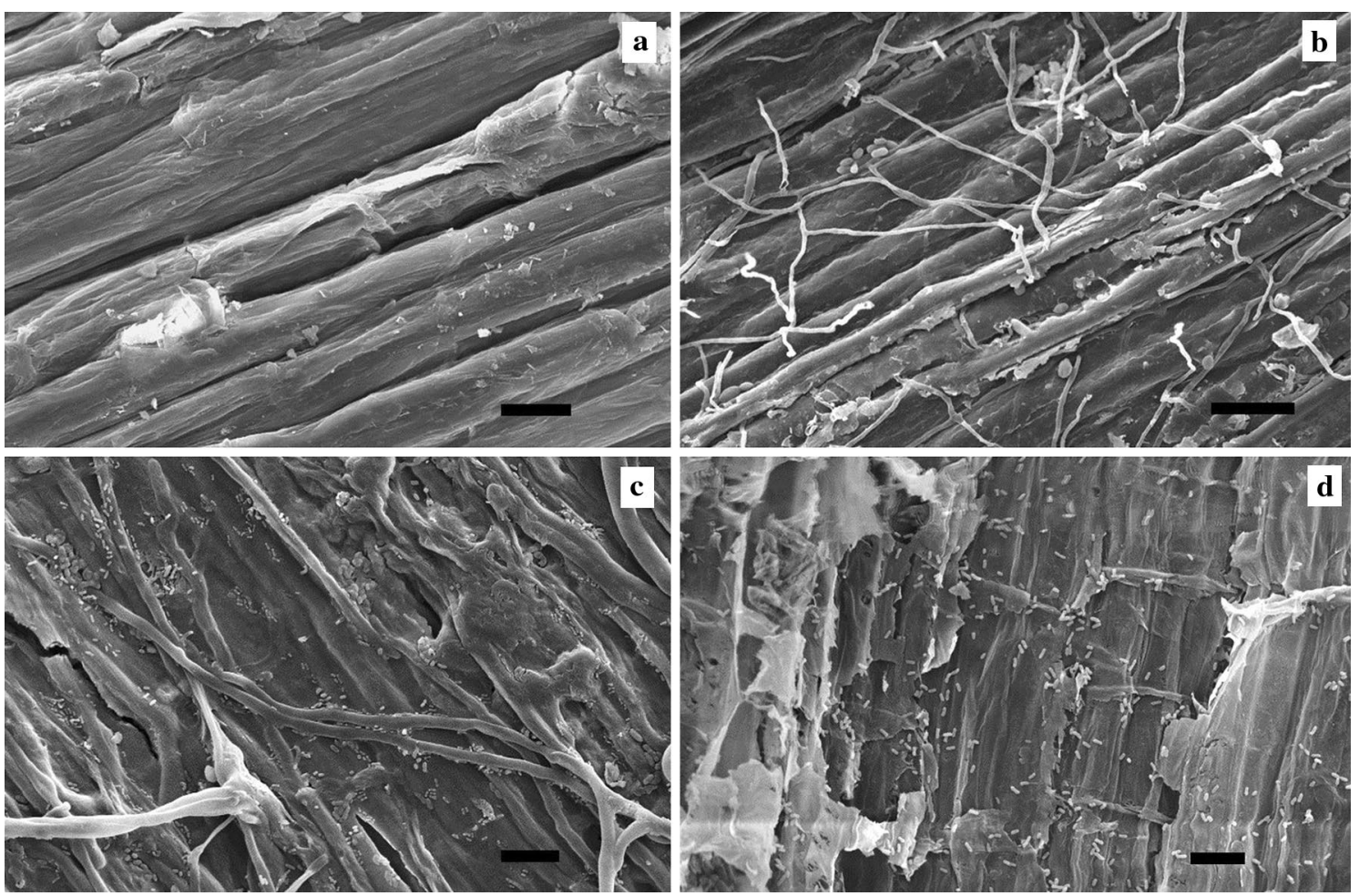

Fig. 1 ESEM microscopy images showing presence of bacteria and fungi in field retted hemp after 0 (a), 7 (b), 14 (c) and 20 days (d). Scale bars $\mathbf{a}$, b $20 \mu \mathrm{m} ; \mathbf{c}, \mathbf{d}, 10 \mu \mathrm{m}$

Table 2 Phylogenetic frequency and affiliation of bacteria on hemp fibres retted for different times

\begin{tabular}{|c|c|c|c|c|c|c|c|}
\hline \multirow[t]{3}{*}{ Phylum } & \multicolumn{2}{|l|}{ Bacterial species } & \multirow{2}{*}{\multicolumn{4}{|c|}{$\begin{array}{l}\% \text { of total bacterial community } \\
\text { Field retting time (day) }\end{array}$}} & \multirow{3}{*}{$\begin{array}{l}\text { Accession number } \\
\text { Old (similarity-\%) new }\end{array}$} \\
\hline & \multirow[t]{2}{*}{ Genus } & \multirow[t]{2}{*}{ Species } & & & & & \\
\hline & & & 0 & 7 & 14 & 20 & \\
\hline \multirow[t]{2}{*}{ a-Proteo-bacteria } & Rhizobium & soli & 0 & $14[1]$ & $17[2]$ & $16[5]$ & NR1 15996 (97\%) LT622055 \\
\hline & Sphingomonas & aerolata & 0 & 0 & $8[1]$ & $3[1]$ & NR042130 (98\%) LT622056 \\
\hline B-Proteo-bacteria & Massilia & aurea & 0 & $14[1]$ & $25[3]$ & $16[5]$ & NR042502 (99\%) LT622057 \\
\hline \multirow[t]{7}{*}{$\gamma$-Proteobacteria } & Erwinia & aphidicola & 0 & 0 & $8[1]$ & $3[1]$ & NR104724 (99\%) LT622058 \\
\hline & \multirow[t]{2}{*}{ Pantoea } & \multirow[t]{2}{*}{ agglomerans brenneri } & 0 & 0 & 0 & $16[5]$ & NR041978 (99\%) LT622059 \\
\hline & & & 0 & 0 & 0 & $3[1]$ & NR1 16748 (99\%) LT622060 \\
\hline & \multirow[t]{3}{*}{ Pseudomonas } & \multirow{3}{*}{$\begin{array}{l}\text { argentinensis } \\
\text { rhizosphaera } \\
\text { syringae }\end{array}$} & 0 & $14[1]$ & 0 & $10[3]$ & NR043115 (97\% LT622061 \\
\hline & & & 0 & $14[1]$ & $8[1]$ & $3[1]$ & NR029063 (99\%) LT622062 \\
\hline & & & 0 & 0 & $8[1]$ & $3[1]$ & NR074597 (99\%) LT622063 \\
\hline & Shigella & sonnei & 0 & $29[2]$ & $8[1]$ & 0 & NR074894 (96\%) LT622064 \\
\hline \multirow[t]{5}{*}{ Bacteroidetes } & Chryseobacterium & scophthalmum & 0 & 0 & 0 & $6[2]$ & NR025386 (97\%) LT622065 \\
\hline & \multirow[t]{2}{*}{ Hymenobacter } & \multirow{2}{*}{$\begin{array}{l}\text { ginsengisoli } \\
\text { norwichensis }\end{array}$} & 0 & 0 & 0 & $3[1]$ & NR108904 (96\%) LT622066 \\
\hline & & & 0 & 0 & 0 & $10[3]$ & NR042172 (99\%) LT622067 \\
\hline & \multirow[t]{2}{*}{ Pedobacter } & \multirow{2}{*}{$\begin{array}{l}\text { hartonius } \\
\text { namyangjuensis }\end{array}$} & 0 & 0 & $8[1]$ & $3[1]$ & NR104917 (95\%) LT622068 \\
\hline & & & 0 & 0 & 0 & $3[1]$ & NR1 13980 (97\%) LT622069 \\
\hline Totals \% [no. clones] & & & $0[0]$ & $100[7]$ & $100[12]$ & $100[31]$ & \\
\hline
\end{tabular}

\footnotetext{
a Percentage based on total number of sequences for each retting period. In brackets is the number of clones identified
} 
Table 3 Phylogenetic frequency and affiliation of fungi on hemp fibres retted for different times

\begin{tabular}{|c|c|c|c|c|c|c|c|}
\hline \multirow[t]{2}{*}{ Phylum } & \multicolumn{2}{|l|}{ Fungal species } & \multicolumn{4}{|c|}{$\begin{array}{l}\% \text { of fungal community } \\
\text { Field retting time (day) }\end{array}$} & \multirow{2}{*}{$\begin{array}{l}\text { Accession number } \\
\text { Old (similarity-\%) new }\end{array}$} \\
\hline & Genus & Species & भетие & 7 & 14 & 20 & \\
\hline \multirow[t]{8}{*}{ Ascomycota } & \multirow[t]{2}{*}{ Alternaria } & brassicae & $0[0]$ & $4[1]$ & $0[0]$ & $3[1]$ & KJ728680 (100\%) LT622070 \\
\hline & & infectoria & $2[1]$ & $7[2]$ & $9[3]$ & $20[6]$ & KC254057 (93\%) LT622071 \\
\hline & \multirow[t]{3}{*}{ Cladosporium } & antarcticum & 7 [3] & $0[0]$ & $0[0]$ & $0[0]$ & NR121332 (100\%) LT622072 \\
\hline & & macrocarpum & $9[4]$ & $0[0]$ & $0[0]$ & $3[1]$ & KC311478 (100\%) T622073 \\
\hline & & uredinicola & $21[9]$ & $50[14]$ & $16[5]$ & $33[10]$ & KP216999 (100\%) LT622074 \\
\hline & Gibellulopsis & nigrescens & $0[0]$ & $0[0]$ & $3[1]$ & $0[0]$ & HE972037 (99\%) LT622075 \\
\hline & Leptospora & rubella & $2[1]$ & $0[0]$ & $0[0]$ & $0[0]$ & HE774478 (95\%) LT622076 \\
\hline & Stemphylium & globuliferum & $26[11]$ & $18[5]$ & $66[21]$ & $40[12]$ & KF479193 (99\%) LT622077 \\
\hline \multirow[t]{8}{*}{ Basidiomycota } & Bulleromyces & albus & $2[1]$ & $4[1]$ & $0[0]$ & $0[0]$ & KC455879 (99\%) LT622078 \\
\hline & \multirow[t]{3}{*}{ Cryptococcus } & carnescens & 5 [2] & $0[0]$ & $0[0]$ & $0[0]$ & JX188120 (100\%) LT622079 \\
\hline & & festucosus & $0[0]$ & $4[1]$ & $0[0]$ & $0[0]$ & FR717832 (98\%) LT622080 \\
\hline & & victoriae & 5 [2] & $11[3]$ & $0[0]$ & $0[0]$ & KM376379 (98\%) LT622081 \\
\hline & Dioszegia & hungarica & $2[1]$ & $0[0]$ & $0[0]$ & $0[0]$ & EU286794 (99\%) LT622082 \\
\hline & Entyloma & microsporum & $2[1]$ & $0[0]$ & $0[0]$ & $0[0]$ & AY081045 (94\%) LT622083 \\
\hline & Rhodotorula & aurantiaca & $2[1]$ & $0[0]$ & $0[0]$ & $0[0]$ & AB093528 (99\%) LT622084 \\
\hline & Sporobolomyces & coprosmae & $7[3]$ & $4[1]$ & $0[0]$ & $0[0]$ & KJ701199 (100\%) LT622085 \\
\hline Totals \% [no. clones] & & & $100[43]$ & $100[28]$ & $100[32]$ & $100[30]$ & \\
\hline
\end{tabular}

a Percentage based on total number of sequences for each retting period. In brackets is the number of clones identified

field retting fungal hyphae were abundant but very few bacteria were observed (Fig. 1b). After 14 days, fungi were present on the hemp fibre surfaces as on fibres retted for 7 days, and bacterial proliferation was also evident and sometimes observed associated with fungal hyphae (Fig. 1c). In addition, spots of local decay on the fibre surface were observed. After 20 days, a higher bacterial population was observed all over the fibre surfaces while fungal hyphae abundance was decreased (Fig. 1d). Severe degradation of the fibre surface was observed at the locations with high bacterial colonization.

\section{Bacterial community}

16S rRNA from samples with different field retting durations was analyzed for bacterial diversity resulting in a total of 81 different sequences (Table 2). Sequences were grouped according to phylum affiliation including $\alpha-\beta-\gamma$-proteobacteria and Bacteroidetes (Table 2). In the unretted sample, no bacteria were found, but the sequencing identified chloroplast originating from the epidermis part of the plant stem (Vergara et al. 2016). From visual inspection, the green colour of chloroplast of the stems disappeared later. After 7 days retting, 14, 14 , and $57 \%$ of the bacterial diversity belonged to $\alpha-, \beta$-, and $\gamma$-proteobacteria, respectively. After 20-days retting, the frequency percentages of $\alpha$ - and $\beta$-Proteobacteria were similar (19 and 16\% of the bacteria) and that of $\gamma$-proteobacteria decreased to $38 \%$. Bacteroidetes were identified after 14 and 20 days of retting with 8 and 25\% of the bacteria, respectively.

The most frequent phylotype was Massilia aurea after 7 and 14 days retting with frequencies of 14 and $25 \%$, respectively, decreasing to $16 \%$ after 20 days. Rhizobium soli constituted $14-17 \%$ of the bacterial diversity during the whole retting period. The Pseudomonas fraction of the bacteria (including the species argentinensis, rhizosphaera and syringae) decreased from $28 \%$ after 7 days to $16 \%$ after 14-20 days. The Shigella sonnei part of the bacteria decreased from 29 to $0 \%$ after 20 days. In addition minor but increasing percentages $(0 \rightarrow 3-10 \%$ of bacteria) were found for Erwinia aphidicola, Chryseobacterium scophthalmum, Hymenobacter sp. and Pedobacter sp.

Figure $2 \mathrm{a}$ shows the genetic differences between the identified bacteria. It shows that few bacterial specie were present initially (7 days) and the evolution of a more varied bacterial community after 14 days with six yellow labels and an even more diverse community after 20 days with 13 orange labels.

\section{Fungal community}

Sequences of the fungal community derived from the ITS gene corresponded to five genera distributed within the Basidiomycota phylum and to six genera within the Ascomycota phylum (Table 3). Between 0 and 7 days of retting, the fungal community was dominated by Ascomycota 


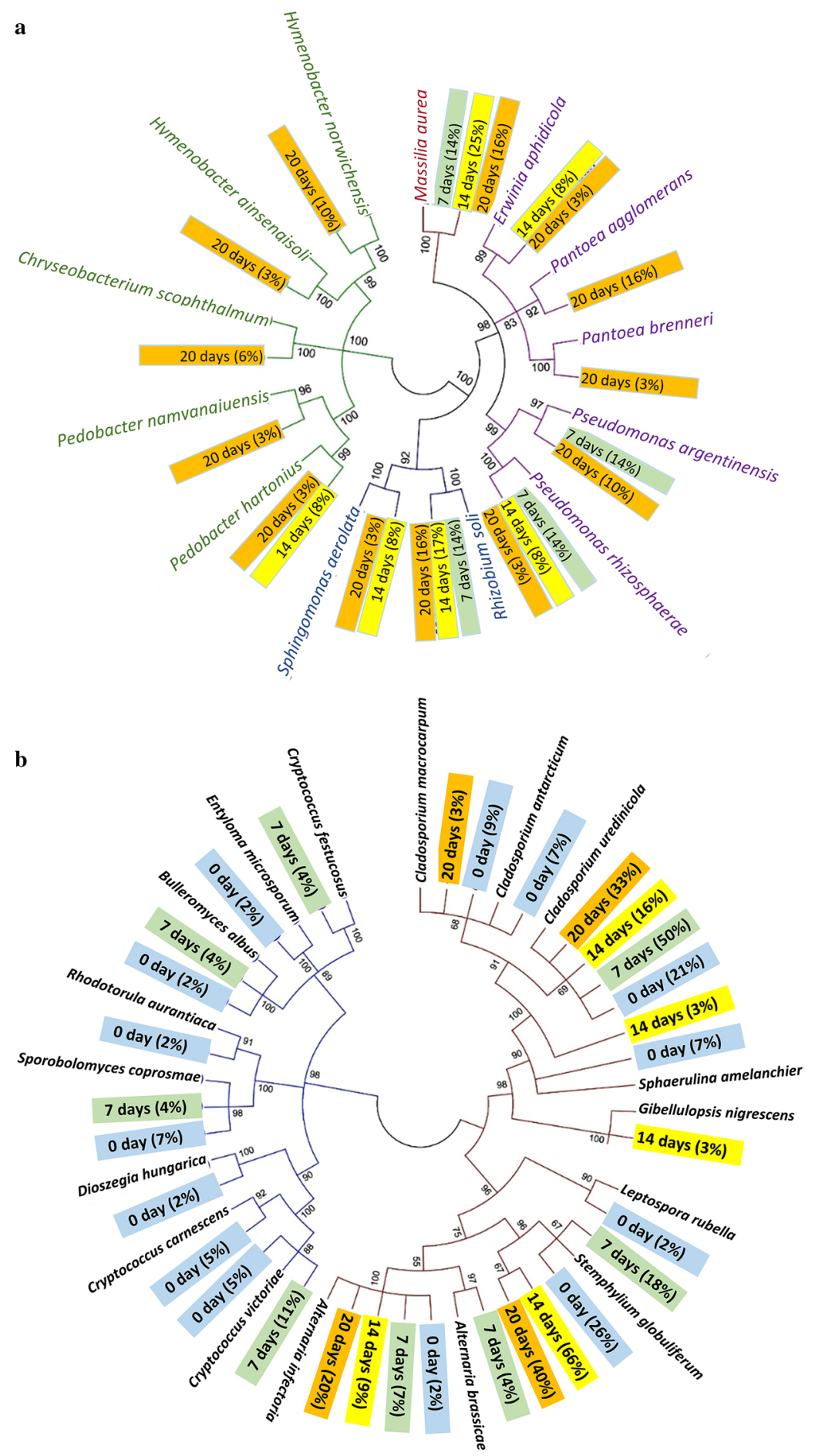

Fig. 2 Phylogenetic tree of bacterial community (a) and fungal community (b) present in the hemp fibre samples. The numbers in the figures show the bootstrap values between the branches. In $\mathbf{a} \alpha-, \beta$-, and $\gamma$-proteobacteria have blue, brown and purple braches, respectively, while Bacteroidetes have green branches. In b Ascomycota and Basidiomycota fungi have brown and blue branches, respectively. Relative abundance is shown in \% calculated based on the number of bacterial (a) and fungal $(\mathbf{b})$ clones at each retting time. Samples are sorted according to retting time $(0$ days $=b / u e ;$ 7 days $=$ green; 14 days $=$ yellow; 20 days $=$ orange) 
contributing $74 \%$ of the diversity increasing to $100 \%$ after 14 days of retting. Stemphylium globuliferum was the most frequent species with $18-66 \%$ of the fungal community. Increases in frequency percentages were both observed for Cladosporium uredinicola $(16 \rightarrow 33 \%)$ and Alternaria infectoria $(9 \rightarrow 20 \%)$. However C. uredinicola dominated initially contributing $50 \%$ of the diversity in the fungal community after 7 days. Low and decreasing frequency percentages of Cryptococcus (including the species carnescens, festucosus and victoriae) and Sphaerulina amelanchier were observed with 10 and $7 \%$ of the fungal community after 0 days, respectively.

Figure $2 b$ shows the genetic differences between the identified fungi and the extinction of Basidiomycota after 14 days of retting, presumably as a result of faster growth of Ascomycota fungi. The analysis also indicates that many well-known fungal species were present initially with 14 blue labels showing a high biodiversity. With time, the diversity of the fungal community decreased as evident from the decrease to only four orange labels after 20 days represented by Alternaria, Stemphylium and Cladosporium (Fig. 2b). This trend was opposite to the increasing diversity of the bacterial community during retting as illustrated in Fig. 2a.

\section{Enzyme activity changes during field-and fungal retting}

Figure 3 shows protein content and enzyme activities of the enzyme crude extracts from field retted and $P$. radiata Cel 26 retted samples at varied retting durations. As shown in Fig. 3a, enzyme extracts from $P$. radiata Cel

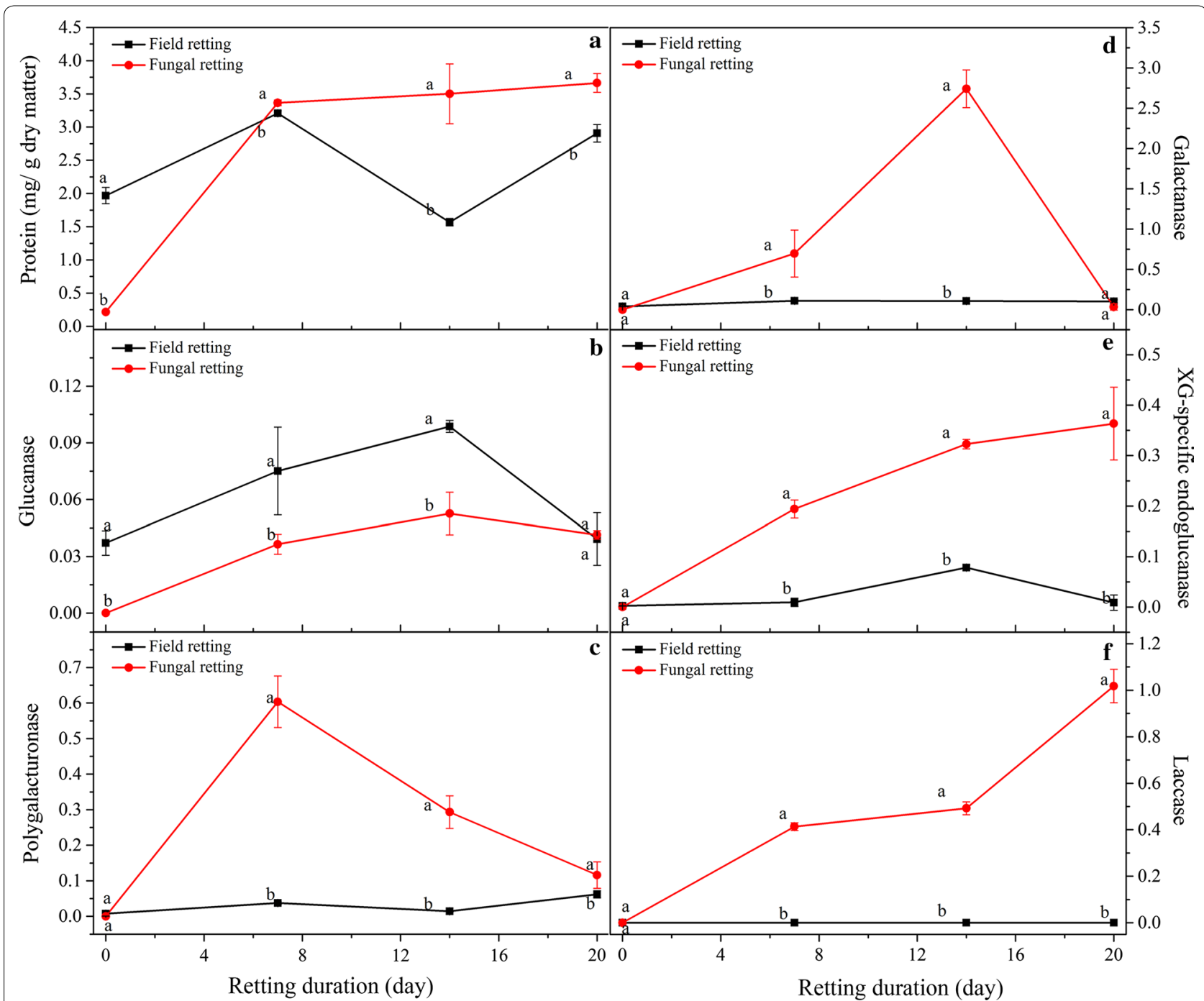

Fig. 3 Protein content of enzyme extracts (a), and enzyme activities of glucanase (b), polygalacturonase (c), galactanase (d), XG-specific endoglucanase $(\mathbf{e})$, and laccase $(\mathbf{f})$ versus retting duration (Units of enzyme activities were shown as $\mathrm{U} / \mathrm{g}$ dry of matter hemp fibres) 
26 retted fibres had higher protein content compared to that from field retted fibres after 14-20 days. Comparison of different enzyme activities in extracts from fieldand $P$. radiata Cel 26 retted fibres, showed that field retted fibres had significantly higher glucanase activity $(0.03 \mathrm{U} / \mathrm{g}$ fibres) up to 20 days (Fig. 3b). High glucanase present in the extracts from field retted fibres corroborated with the chemical composition data (Table 1: low cellulose content) and microbial community evolution during field retting (Tables 2, 3: cellulose degrading microorganisms).

Much higher polygalacturonase activity in the extracts from $P$. radiata Cel 26 retted fibres of $0.6 \mathrm{U} / \mathrm{g}$ fibres was observed after 7 days compared to that extracted from field retted fibres $(0.05 \mathrm{U} / \mathrm{g}$ fibres). Thereby the more efficient pectin degradation by fungal retting (Table 1) can be corroborated by the high polygalacturonase activity present in the enzyme extracts from $P$. radiata Cel 26 retted fibres (Fig. 3c). The polygalacturonase activity obtained with $P$. radiata Cel 26 gradually decreased to $0.1 \mathrm{U} / \mathrm{g}$ DM after 20 days.

Besides glucanase and polygalacturonase activities, galactanase, XG-specific endoglucanase, and laccase activities were determined for both field retted and $P$. radiata Cel 26 retted fibres. $P$. radiata Cel 26 retted fibres exhibited higher galactanase and XG-specific endo-glucanase activity than field retted fibres. Laccase activity was found to increase with extended $P$. radiata Cel 26 retting duration from $0.4 \mathrm{U} / \mathrm{g}$ DM after 7 days to $1.0 \mathrm{U} / \mathrm{g}$ $\mathrm{DM}$ after 20 days, while no laccase activity was detected in the crude enzyme extracts from field retted fibres (Fig. 3f).

\section{Mechanical properties of fibres and fibre/epoxy composites \\ Fibre bundle strength}

The stiffness and UTS of the fibres are shown in Table 4 while the composite derived data are shown in Table 5 . The untreated hemp fibres had stiffness of $29 \mathrm{GPa}$ and UTS of $770 \mathrm{MPa}$. A decrease in fibre strength was observed with increased field retting duration to $683 \mathrm{MPa}$ after 20 days (Table 4). The decrease in fibre strength can be explained by the loss of cellulose because of cellulase activities (Fig. 3b). For P. radiata Cel 26 retted fibres, the stiffness increased and UTS decreased slightly. After fibres were retted with $P$. radiata Cel 26 for 14 days, the stiffness and UTS of fibres were $42 \mathrm{GPa}$ and $720 \mathrm{MPa}$. Only slight changes were observed on strength and stiffness by 30 and 60 min of HTT pretreatment. However HTT treatment appeared to increase fibre stiffness and strength slightly when followed by pectinase treatment.
Table 4 Mechanical properties of hemp fibres after different treatments

\begin{tabular}{lllll}
\hline Treatment & Period & Stiffness (GPa) & UTS (MPa) & Strain (\%) \\
\hline Untreated & 0 & $29(3)^{\mathrm{cd}}$ & $772(104)^{\mathrm{ab}}$ & $5.0(0.9)^{\mathrm{a}}$ \\
HTT $^{\mathrm{A}}$ & $30 \mathrm{~min}$ & $31(6)^{\mathrm{cd}}$ & $688(120)^{\mathrm{bc}}$ & $2.9(0.7)^{\mathrm{de}}$ \\
HTT & $60 \mathrm{~min}$ & $32(5)^{\mathrm{bc}}$ & $785(180)^{\mathrm{ab}}$ & $2.8(0.7)^{\mathrm{de}}$ \\
Field retting & 7 days & $33(5)^{\mathrm{bc}}$ & $832(198)^{\mathrm{a}}$ & $4.7(1.8)^{\mathrm{a}}$ \\
& 14 days & $31(5)^{\mathrm{cd}}$ & $697(104)^{\mathrm{bc}}$ & $4.5(1.5)^{\mathrm{ab}}$ \\
& 20 days & $28(5)^{\mathrm{cd}}$ & $683(107)^{\mathrm{bc}}$ & $4.5(1.2)^{\mathrm{ab}}$ \\
Fungal retting & 7 days & $27(5)^{\mathrm{d}}$ & $707(130)^{\mathrm{a}}$ & $3.6(0.9)^{\mathrm{bcd}}$ \\
& 14 days & $42(5)^{\mathrm{a}}$ & $720(150)^{\mathrm{abc}}$ & $2.3(0.5)^{\mathrm{e}}$ \\
& 20 days & $31(7)^{\mathrm{cd}}$ & $714(145)^{\mathrm{bc}}$ & $3.1(0.8)^{\mathrm{cde}}$ \\
Pectinase $^{\mathrm{A}}$ & 90 min & $18(4)^{\mathrm{e}}$ & $636(61)^{\mathrm{c}}$ & $3.8(0.9)^{\mathrm{bc}}$ \\
HTT + pectinase $^{\mathrm{A}}$ & 90 min & $36(5)^{\mathrm{b}}$ & $777(117)^{\mathrm{ab}}$ & $2.6(0.9)^{\mathrm{e}}$ \\
\hline
\end{tabular}

Values are shown as mean (standard error). In each column, values that do not share a letter are significantly different at the $5 \%$ level

A With or without autoclave treatment (HTT) at 1 bar $\left(121^{\circ} \mathrm{C}\right)$ for $30 \mathrm{~min}$ before the pectinase treatment (Liu et al. 2016b)

\section{Fibre reinforced composite results}

All fungal retted and untreated fibres were assessed in hemp fibre/epoxy composites. In order to compare with traditional field retting, the 20-day field retted fibres were also assessed. As shown in Fig. 4a, the starting points of the linear regression lines at $\mathrm{V}_{\mathrm{f}}=0$, showed the measured epoxy matrix stiffness $\left(\mathrm{E}_{\mathrm{m}}\right)$ of $2.7 \mathrm{GPa}$. By comparison of the slopes $(k)$ of the lines of $E_{c}$ versus $V_{f}$, of composites with differently treated fibres, it can be seen that composites with $P$. radiata Cel 26 retted fibres, irrespective of retting duration, had much higher stiffness and strength than with field retted fibres (Fig. 4). The composite stiffness and strength at $\mathrm{V}_{\mathrm{f}}=50 \%$ were determined and shown in Table 5. The composite strength and stiffness were retained by the retting with $P$. radiata Cel 26 for 7-20 days with 32-35 GPa and 283-307 MPa, respectively. This treatment effect is thereby similar to pectinase treatment and better than field retting giving only 306 and $248 \mathrm{MPa}$, respectively.

The effective fibre stiffness $\left(\mathrm{E}_{\mathrm{f}}\right)$ and strength $\left(\mathrm{UTS}_{\mathrm{f}}\right)$ were estimated by linear regression within the $V_{f}$ range tested (Table 5). It was confirmed by correlation analysis that there was a linear increase in the tested $V_{f}$ range with at least $99 \%$ significance. The untreated hemp fibres had $\mathrm{E}_{\mathrm{f}}$ of $65 \mathrm{GPa}$. $\mathrm{E}_{\mathrm{f}}$ was determined to be similar $(62,66$ and $67 \mathrm{GPa}$ ) for 7-, 14-, and 20-days retted samples using $P$. radiata Cel 26, respectively. In contrast, 20 days field retted fibres showed that $\mathrm{E}_{\mathrm{f}}$ was only $51 \mathrm{GPa}$. If $P$. radiata Cel 26 retting was replaced with pectinase treatment higher stiffness of $74 \mathrm{GPa}$ was obtained. The results demonstrate thereby that $P$. radiata Cel 26 retting produced better fibres than field retting. 
Table 5 Mechanical properties of hemp fibre composites after the different treatments

\begin{tabular}{|c|c|c|c|c|c|c|}
\hline \multirow[t]{2}{*}{ Treatment } & \multirow[t]{2}{*}{ Period } & \multicolumn{3}{|c|}{ Composite properties $\left(V_{f}=50 \%\right)$} & \multicolumn{2}{|c|}{ Calculated fibre properties } \\
\hline & & $\begin{array}{l}\text { Stiffness } \\
\mathrm{E}_{\mathrm{c}}(\mathrm{GPa})\end{array}$ & $\begin{array}{l}\text { UTS }_{c} \\
\text { (MPa) }\end{array}$ & $\begin{array}{l}\text { Porosity } \\
V_{p}(\%)\end{array}$ & $\begin{array}{l}\mathrm{E}_{\mathrm{f}} \\
(\mathrm{GPa})\end{array}$ & $\begin{array}{l}\text { Porosity } \\
a_{\mathrm{pf}}(\%)\end{array}$ \\
\hline Untreated & 0 & $33.8(0.6)$ & $294(14)$ & $7.9(0.4)$ & $64.9(1.2)$ & $15.7(0.8)$ \\
\hline Field retted & 20 days & $26.9(0.6)$ & $248(17)$ & $8.1(0.6)$ & $51.2(1.1)$ & $16.2(1.2)$ \\
\hline \multirow[t]{3}{*}{ Fungal retting } & 7 days & $32.2(0.5)$ & $283(8)$ & $6.6(0.8)$ & $61.6(0.9)$ & $13.1(1.5)$ \\
\hline & 14 days & $34.5(0.5)$ & $300(9)$ & $4.9(0.4)$ & $66.2(0.9)$ & $9.7(0.7)$ \\
\hline & 20 days & $34.8(0.3)$ & $307(6)$ & $5.5(0.5)$ & $66.9(0.6)$ & $10.9(0.9)$ \\
\hline Pectinase $^{A}$ & $90 \mathrm{~min}$ & $35.2(1.0)$ & $306(15)$ & $6.0(0.3)$ & $67.6(1.9)$ & $11.9(0.6)$ \\
\hline $\mathrm{HTT}+$ pectinase $^{\mathrm{A}}$ & $90 \mathrm{~min}$ & $38.2(0.8)$ & $325(6)$ & $4.2(0.2)$ & $73.6(1.6)$ & $8.4(0.4)$ \\
\hline
\end{tabular}

Values are means (standard error)

A With or without autoclave treatment (HTT) at 1 bar $\left(121^{\circ} \mathrm{C}\right)$ for 30 min before the pectinase treatment (Liu et al. 2016b)

The porosity factors $\left(\alpha_{\mathrm{pf}}\right)$ of composites with differently treated fibres were determined by Eq. (1) based on the experimental data of $V_{p}$ versus $V_{f}$. In general, $V_{p}$ increased versus $V_{f}$ due to voids corresponding to cell lumen and unimpregnated void space between fibre bundles. As shown in Fig. 4c, composites with field retted and untreated fibres had the highest porosity factor (up to 0.16 ), followed by composites with $P$. radiata Cel 26 retted fibres $(0.10-0.13)$. For composites made with $P$. radiata Cel 26 retted fibres, the composite porosity was found to decrease vs. the retting duration due to smaller fibre bundles in general obtained with more defibration (Thygesen et al. 2007; Liu et al. 2016a).

\section{Discussion}

\section{Microbial community and enzyme expression}

Field retting based on natural microbial communities and $P$. radiata Cel 26 retting was assessed in hemp fibre treatment for fibre/epoxy composites and compared with a pure enzymatic approach. The changes in chemical composition of the hemp fibres was consistent with a previous study where field retting caused greater loss of cellulose with increased duration (Liu et al. 2015a), while fungal retting with $P$. radiata $\mathrm{Cel} 26$ did not degrade the cellulose (Liu et al. 2015b). It is a strong indication for cellulase production recorded during field retting (Fig. 3b) due to the presence of wild microbial populations. Normally with these types of wild microbial populations, the bacteria associate with the fungal hyphae so that they can get access to carbohydrates released by the fungal attack of the plant cell wall (Boonchan et al. 2000). Therefore the abundance of fungi decreased with extended retting duration, while the abundance and diversity of bacteria increased as observed with ESEM (Figs. 1, 2).

$\gamma$-Proteobacteria as the most abundant phylum in the bacterial community has also been observed with water retting of jute (Corchorus olitorius) (Munshi and Chattoo 2008). $\gamma$-Proteobacteria can hydrolyze cellulose and pectin owing to its cellulolytic and pectinolytic activity (Hrynkiewicz et al. 2010). Rhizobium sp. and Massilia sp. have also been found to produce cellulase enzymes (Morales et al. 1984; Hrynkiewicz et al. 2010), which explains the cell wall degradation at the bacterially colonized sites at late retting stages. Pseudomonas sp. were found to be particularly important in the decomposition of pectin in plant fibres during retting under aerobic conditions (Betrabet and Bhat 1958; Rosemberg 1965).

Endophytic fungi such as S. globuliferum and Cladosporium sp. can penetrate plant tissue while producing pectinase and cellulase enzymes (Brown and Sharma 1984; Wang and Dai 2011). A. infectoria has also been reported to perform enzymatic hydrolysis of cellulose and hemicellulose (Silva et al. 2014). This confirms that pectin and carbohydrate degrading enzymes were produced during field retting giving decay in the hemp fibre cell walls (Table 1 ) and agrees with the measured enzyme activities (Fig. 3). Cryptococcus can produce cutinase enzymes (Masaki et al. 2005) involved in cutin degradation in the cuticle on hemp stem surface, which explains why it was present initially. The zero laccase activity is consistent with the lack of Basidiomycota fungi in field retting. The higher Klason lignin content of the field retted fibres (Table 1 ) is presumably due to the zero laccase activity (Fig. 3, and consistent with lack of ligninolytic Basidiomycota fungi (Table 3).

\section{Fibre compositional changes and resulting composite properties}

Mechanical properties of composites depend not only on fibre strength but also on the hemp fibre-matrix interface adhesion (Gassan et al. 2000). Improved interface adhesion with the fibres can be obtained with a low fibre surface porosity content ( $\mathrm{Li}$ et al. 2009; Liu et al. 2016a). The decrease in composite porosity obtained with $P$. radiata Cel 26 and by pectinase treatment (Fig. 4c) were primarily due to degradation of parenchyma cells 


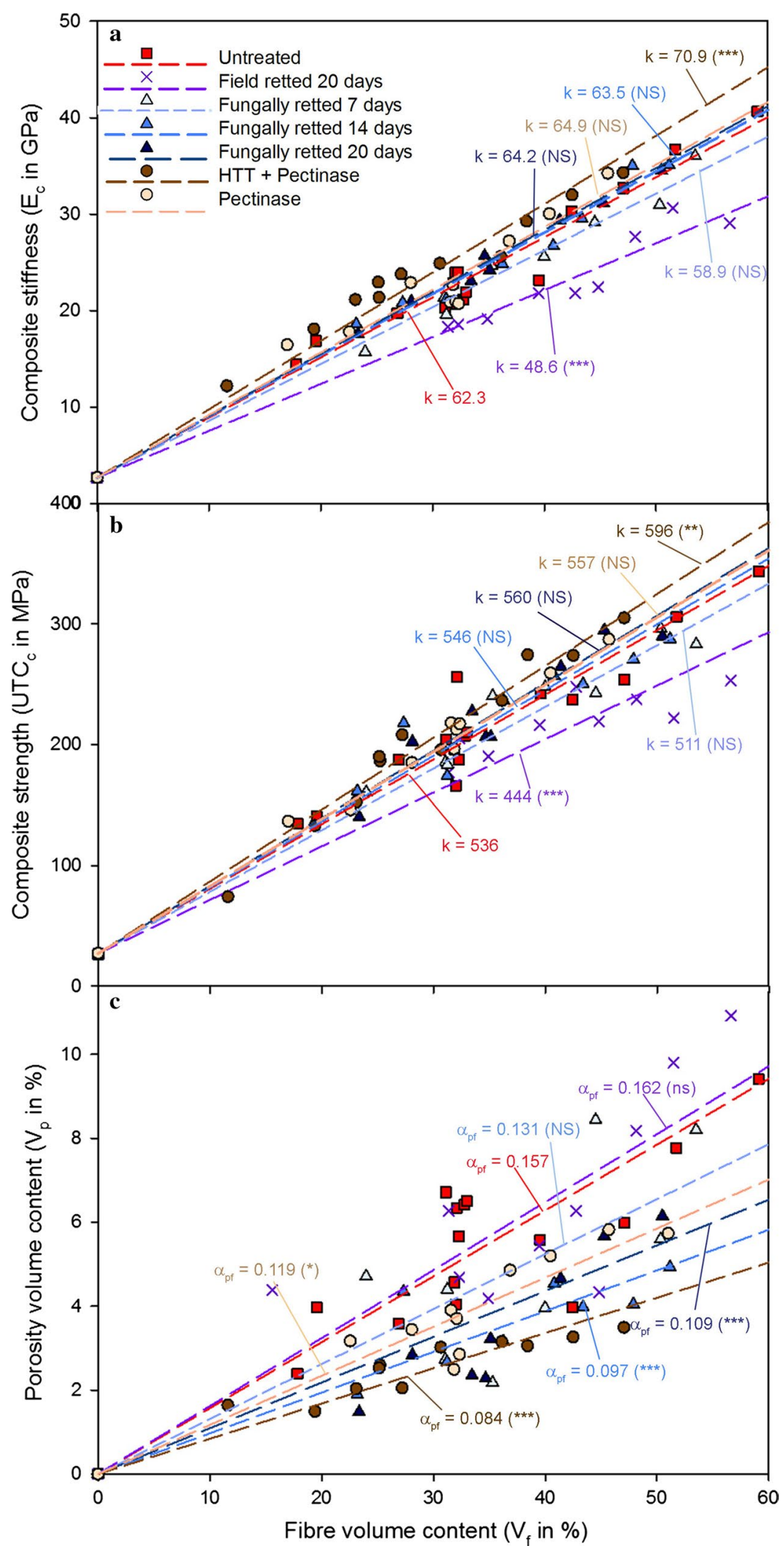

Fig. 4 Stiffness (a), UTS $(\mathbf{b})$ and porosity $(\mathbf{c})$ of composites reinforced with untreated and treated fibres versus fibre volume $\left(V_{f}\right)$ contents $(k$ is slope of the linear regression model lines). Pectinase treatment was performed with and without prior autoclave treatment (HTT) at 1 bar $\left(121^{\circ} \mathrm{C}\right)$ for 30 min (Liu et al. 2016b) 


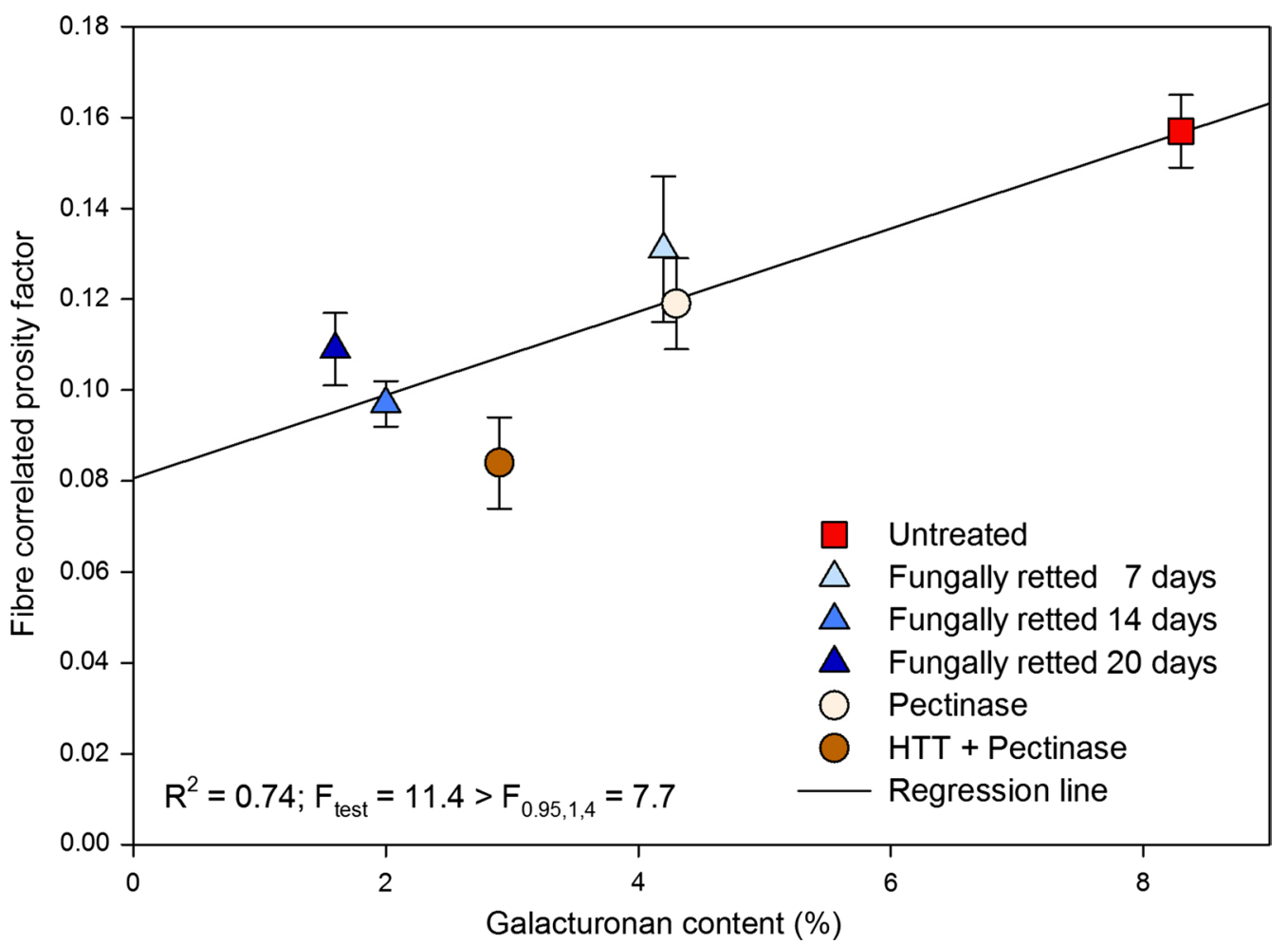

Fig. 5 Correlation between fibre correlated porosity factor $\left(a_{\mathrm{pf}}\right)$ and galacturonan content of fibres after different treatments

mainly consisting of pectin and hemicellulose. The fibre correlated porosity factor increased thereby versus the galacturonan content after retting with $P$. radiata Cel 26 similar with pectinase treatment (Fig. 5). The decrease in composite porosity could thereby explain the slightly better mechanical properties of the composites obtained with the $P$. radiata Cel 26 retted fibres (Fig. 4). However the recorded cellulase activity (Fig. $3 \mathrm{~b}$ ) might have reduced the resulting composite strength and stiffness slightly compared to pectinase treatment (Fig. 4a, b).

The fibre stiffness was two times higher when back calculated based on composite data (Tables 4,5). The high fibre stiffness based on composite data can be explained due to the approximate half failure strain obtained of $1 \%$ in composites. The back calculation for calculation of fibre stiffness has proven to be possible since linear relationships are obtained (Shah et al. 2016). Technical fibres were in this study tested instead of single fibres since cross sectional area is more easily determined and due to bias in the isolation of single fibres from bundles by hand (Charlet et al. 2010).

\section{Perspectives for industrial implementation of fungal defibration}

Comparing untreated hemp and fungal retted hemp slight increases were obtained in fibre stiffness from 65 to $67 \mathrm{MPa}$ and in composite strength (Table 5) while the porosity factor decreased from 0.157 to 0.109 . The obtained decrease in porosity content results in a more homogeneous composite and better fibre-matrix adhesion. In addition, industrial production of untreated hemp fibres cannot be done without damaging the fibres making the field retting the only alternative with much worse properties of $49 \mathrm{GPa}$ and 0.162 for stiffness and porosity factor, respectively. The fungal retting is a simultaneous enzyme production and utilization treatment. Industrial introduction of fungal treatment could be possible in the form of solid state fermentation and would according to this study provide fibres of significantly higher quality than field retting. The maximum composite properties obtained with $P$. radiata Cel 26 were $307 \mathrm{MPa}$ for strength and $35 \mathrm{GPa}$ for stiffness corresponding to $\mathrm{V}_{\mathrm{f}}=51 \%$. These properties were higher than obtained by Thygesen et al. (2007) with $196 \mathrm{MPa}$ and $32 \mathrm{GPa}$, respectively, which was lower due to the lower fibre content of $32 \%$.

\section{Overall concluding perspectives}

Field retting and $P$. radiata Cel 26 retting of hemp were assessed in hemp fibre/epoxy composites and compared with a pure enzymatic retting approach. It was found that the abundance of fungi decreased with extended 
field retting duration, while the abundance of bacteria increased. Field retted fibres exhibited much higher glucanase and lower polygalacturonase activities than $P$. radiata Cel 26 retted fibres. As a result, retting with $P$. radiata Cel 26 could degrade non-cellulosic components from hemp fibres at highest selectivity. Composites with $P$. radiata Cel 26 retted hemp fibres had significantly higher strength (307 MPa) than composites made with field retted hemp fibres (248 MPa). However a pure pectinase approach resulted in even higher composite strength (325 MPa) (Liu et al. 2016b). Despite this disadvantage the fungal treatment has the advantage of giving more pure cellulose and avoiding costs of enzymes for the process.

\begin{abstract}
Abbreviations
ABTS: 2,2'-azino-bis(3-ethylbenzothiazoline)-6-sulfonate; DNA: deoxyribonucleic acid; $E_{c^{\prime}} E_{f}, E_{m}$ : stiffness of composite, fibres and matrix, respectively; ESEM: environmental scanning electron microscopy; HPAEC-PAD: highperformance anion-exchange chromatography with pulsed amperometric detection; ITS: internally transcribed spacer; rRNA: ribosomal ribonucleic acid UTS: ultimate tensile strength; XG: xyloglucan.
\end{abstract}

\section{Authors' contributions}

ML performed the experimental work with fibres and composites, MTA did the microbial classification work, ML, BK and AT did the enzyme work and AT, DF and GD did the ESEM microscopy work. ML, AT and AM conceived the study and analyzed and interpreted the results and wrote the paper. All authors read and approved the final manuscript.

\section{Author details}

${ }^{1}$ Center for Bioprocess Engineering, Department of Chemical and Biochemical Engineering, Technical University of Denmark, Søltofts Plads 229, 2800 Kongens Lyngby, Denmark. ${ }^{2}$ Department of Forest Products/Wood Science, Swedish University of Agricultural Sciences, Vallvägen 9D, 750-07 Uppsala, Sweden.

\section{Acknowledgements}

The authors are grateful to Senior Scientist Dr. Bo Madsen and Mr. Jonas Kreutzfeldt Heininge from Department of Wind Energy, Technical University of Denmark for access and advice on composite production and physical tests.

\section{Competing interests}

The authors declare that they have no competing interests.

\section{Availability of data and materials}

All the data applied in the study are included in the tables and figures presented. All the sequences identifies are published in the EMBL Nucleotide Sequence Database with the accession numbers LT622055-LT622085.

\section{Ethics approval and consent to participate}

This article does not contain any studies with human participants or animals performed by any of the authors.

\section{Funding}

This study was supported by The Danish Council for Independent Research (Project ref. 0602-02409B: "High quality cellulosic fibres for strong biocomposite materials") and by China Scholarship Council (Project ref. 201304910245).

Received: 21 February 2017 Accepted: 23 February 2017

Published online: 09 March 2017

\section{References}

Ale MT, Barrett K, Addico GND, Knudsen NR, Johnson AAGJ, Meyer AS (2016) DNA-based identification and chemical characteristics of Hypnea musciformis from coastal sites in Ghana. Diversity 8(2):14

Arnous A, Meyer AS (2008) Comparison of methods for compositional characterization of grape (Vitis vinifera L.) and apple (Malus domestica) skins. Food Bioprod Process 86:79-86

Benko Z, Siika-aho M, Viikari L, Réczey K (2008) Evaluation of the role of xyloglucanase in the enzymatic hydrolysis of lignocellulosic substrates. Enzyme Microb Technol 43:109-114

Betrabet SM, Bhat JV (1958) Pectin decomposition by species of Pseudomonas and their role in the retting of Malvaceous plants. Appl Microbiol 6:89-93

Boonchan S, Britz ML, Stanley GA (2000) Degradation and mineralization of high-molecular-weight polycyclic aromatic hydrocarbons by defined fungal-bacterial cocultures. Appl Environ Microbiol 66:1007-1019. doi:10.1128/AEM.66.3.1007-1019.2000

Bradford MM (1976) A rapid and sensitive method for the quantitation of microgram quantities of protein utilizing the principle of protein-dye binding. Anal Biochem 72:248-254

Brown AE, Sharma HSS (1984) Production of polysaccharide-degrading enzymes by saprophytic fungi from glyphosate treated flax and their involvement in retting. Anal Appl Biol 105:65-74

Charlet K, Jernot J-P, Gomina M, Bizet L, Bréard J (2010) Mechanical properties of Flax Fibers and of the derived unidirectional composites. J Compos Mater 44(24):2887-2896

Cheung HY, Ho MP, Lau KT, Cardona F, Hui D (2009) Natural fibre-reinforced composites for bioengineering and environmental engineering applications. Compos Part B Eng 40:655-663

Curtin WA (1993) Ultimate strengths of fibre-reinforced ceramics and metals. Composites 24:98-102. doi:10.1016/0010-4361(93)90005-S

Faruk O, Bledzki AK, Fink HP, Sain M (2012) Biocomposites reinforced with natural fibers: 2000-2010. Prog Polym Sci 37:1552-1596

Fernando D, Daniel G (2008) Exploring Scots pine fibre development mechanisms during TMP processing: impact of cell wall ultrastructure (morphological and topochemical) on negative behaviour. Holzforschung 62:597-607

Gardes M, White TJ, Fortin JA, Bruns TD, Taylor JW (1991) Identification of indigenous and introduced symbiotic fungi in ectomycorrhizae by amplification of nuclear and mitochondrial ribosomal DNA. Can J Bot 69:180-190

Gassan J, Gutowski VS, Bledzki AK (2000) About the surface characteristics of natural fibres. Surf Eng 283:132-139

Hrynkiewicz K, Baum C, Leinweber P (2010) Density, metabolic activity, and identity of cultivable rhizosphere bacteria on Salix viminalis in disturbed arable and landfill soils. J Plant Nutr Soil Sci 173:747-756

Kimura M (1980) A simple method for estimating evolutionary rates of base substitutions through comparative studies of nucleotide sequences. J Mol Evol 16:111-120. doi:10.1007/BF01731581

Lever M (1973) Colorimetric and fluorometric carbohydrate determination with p-hydroxybenzoic acid hydrazide. Biochem Med 7:274-281. doi:10.1016/0006-2944(73)90083-5

Li A, Zhu Y, Xu L, Zhu W, Tian X (2008) Comparative study on the determination of assay for laccase of Trametes sp. Afr J Biochem Res 2:181-183

Li Y, Pickering KL, Farrell RL (2009) Determination of interfacial shear strength of white rot fungi treated hemp fibre reinforced polypropylene. Compos Sci Technol 69:1165-1171

Liu M, Fernando D, Daniel G, Madsen B, Meyer AS, Ale MT, Thygesen A (2015a) Effect of harvest time and field retting duration on the chemical composition, morphology and mechanical properties of hemp fibers. Ind Crops Prod 69:29-39

Liu M, Fernando D, Meyer AS, Madsen B, Daniel G, Thygesen A (2015b) Characterization and biological depectinization of hemp fibers originating from different stem sections. Ind Crop Prod 76:880-891

Liu M, Meyer AS, Fernando D, Silva DAS, Daniel G, Thygesen A (2016a) Effect of pectin and hemicellulose removal from hemp fibres on the mechanical properties of unidirectional hemp/epoxy composites. Compos Part A Appl Sci Manuf 90:724-735 
Liu M, Silva DAS, Fernando D, Meyer AS, Madsen B, Daniel G, Thygesen A (2016b) Controlled retting of hemp fibres: effect of hydrothermal pre-treatment and enzymatic retting on the mechanical properties of unidirectional hemp/epoxy composites. Compos Part A Appl Sci Manuf 88:253-262. doi:10.1016/j.compositesa.2016.06.003

Maidak BL, Cole JR, Parker CT, Garrity GM, Larsen N, Li B, Lilburn TG, McCaughey MJ, Olsen GJ, Overbeek R, Pramanik S, Schmidt TM, Tiedje JM, Woese CR (1999) A new version of the RDP (Ribosomal Database Project). Nucleic Acids Res 27:171-173. doi:10.1093/nar/27.1.171

Masaki K, Kamini NR, lefuji H (2005) Cutinase-like enzyme from the yeast Cryptococcus sp. strain S-2 hydrolyzes polylactic acid and other biodegradable plastics. Appl Environ Microbiol 71:7548-7550. doi:10.1128/ AEM.71.11.7548

Michalak M, Thomassen LV, Roytio H, Ouwehand AC, Meyer AS, Mikkelsen JD (2012) Expression and characterization of an endo-1,4- $\beta$-galactanase from Emericella nidulans in Pichia pastoris for enzymatic design of potentially prebiotic oligosaccharides from potato galactans. Enzyme Microb Technol 50:121-129

Morales VM, Martinez-Molina E, Hubbell DH (1984) Cellulase production by Rhizobium. Plant Soil 80:407-415. doi:10.1007/BF02140047

Munshi TK, Chattoo BB (2008) Bacterial population structure of the jute-retting environment. Microb Ecol 56:270-282

Nyhlen L, Nilsson T (1987) Combined TEM and UV-microscopy on delignification of pine wood by Phlebia radiata and four other white rotters. In: Odier E (ed). INRA Publications, Versailles, pp 277-282

Ribeiro A, Pochart P, Day A, Mennuni S, Bono P, Baret JL, Spadoni JL, Mangin I (2015) Microbial diversity observed during hemp retting. Appl Biochem Biotechnol 99:4471-4484

Rosemberg JA (1965) Bacteria responsible for the retting of Brazilian flax. Appl Microbiol 13:991-992

Shah DU, Nag RK, Clifford MJ (2016) Why do we observe significant differences between measured and "back-calculated" properties of natural fibres? Cellulose 23:1481-1490. doi:10.1007/s10570-016-0926-x

Silva BMA, Prados-Rosales R, Espadas-Moreno J, Wolf JM, Luque-Garcia JL, Gonçalves T, Casadevall A (2014) Characterization of Alternaria infectoria extracellular vesicles. Med Mycol 52:202-210. doi:10.1093/mmy/myt003

Sluiter A, Hames B, Ruiz R, Scarlata C, Sluiter J, Templeton D, Crocker D (2011) Determination of structural carbohydrates and lignin in biomass
Srinivasan C, D'Souza T, Boominathan K, Reddy C (1995) Demonstration of laccase in the white-rot basidiomycete Phanerochaete chrysosporium BKM-F-1767. Appl Environ Microbiol 61:4274-4277

Sun G, Thygesen A, Meyer AS (2015) Acetate is a superior substrate for microbial fuel cell initiation preceding bioethanol effluent utilization. Appl Microbiol Biotechnol 99:4905-4915. doi:10.1007/s00253-015-6513-5

Suwannarangsee S, Arnthong J, Eurwilaichitr L, Champreda V (2014) Production and characterization of multi-polysaccharide degrading enzymes from Aspergillus aculeatus BCC199 for saccharification of agricultural residues. J Microbiol Biotechnol 24:1427-1437

Thomassen LV, Larsen DM, Mikkelsen JD, Meyer AS (2011) Definition and characterization of enzymes for maximal biocatalytic solubilization of prebiotic polysaccharides from potato pulp. Enzyme Microb Technol 49:289-297

Thompson JD, Higgins DG, Gibson TJ, Clustal W (1994) Improving the sensitivity of progressive multiple sequence alignment through sequence weighting, position-specific gap penalties and weight matrix choice. Nucleic Acids Res 22:4673-4680

Thygesen A, Thomsen AB, Daniel G, Lilholt H (2007) Comparison of composites made from fungal defibrated hemp with composites of traditional hemp yarn. Ind Crops Prod 25:147-159

Vergara D, White KH, Keepers KG, Kane NC (2016) The complete chloroplast genomes of Cannabis sativa and Humulus lupulus. Mitochondrial DNA Part A 27(5):3793-3794

Wang Y, Dai CC (2011) Endophytes: a potential resource for biosynthesis, biotransformation, and biodegradation. Ann Microbiol 61:207-215. doi:10.1007/s13213-010-0120-6

White TJ, Bruns T, Taylor J (1990) Amplification and direct sequencing of fungal ribosomal RNA Genes for phylogenetics. In: Innis MA, Gelfand DH, Sninsky JJ, White TJ (eds) PCR protocols: a guide to methods and applications. Academic Press, New York, pp 315-322

\section{Submit your manuscript to a SpringerOpen ${ }^{\circ}$ journal and benefit from:}

- Convenient online submission

- Rigorous peer review

Immediate publication on acceptance

- Open access: articles freely available online

- High visibility within the field

- Retaining the copyright to your article

Submit your next manuscript at $\boldsymbol{\nabla}$ springeropen.com 